\title{
PENGARUH MODEL PEMBELAJARAN INKUIRI TERBIMBING TERHADAP KREATIVITAS SISWA PADA MATERI LARUTAN PENYANGGA
}

\author{
Susanti, Putri Ayu Mutmainnah, Sry Agustina dan Ruslan
}

Prodi Pendidikan Kimia STKIP Bima

email : susantiantii22@hmail.com

\begin{abstract}
ABSTRAK
Penelitian ini bertujuan untuk mengetahui ada tidaknya pengaruh model pembelajaran inkuiri terbimbing terhadap kreativitas siswa pada materi larutan penyangga. Jenis penelitian yang digunakan adalah quasi experimental design dan menggunakan desain posttest-only control design. Penelitian ini dilakukan pada siswa kelas XI IPA SMA Negeri 2 Kota Bima. Populasi penelitian terdiri dari enam kelas dengan jumlah 142 siswa dan sampel diambil dari dua kelas yang utuh yaitu 23 siswa dari kelas XI MIA 5 sebagai kelas eksperimen dengan model inkuiri terbimbing dan 23 siswa dari kelas XI MIA 6 sebagai kelas kontrol dengan model penusan langsung, Pengambilan data menggunakan instrumen tes kreativitas siswa pada materi larutan penyangga. Data dianalisis menggunakan aplikasi SPSS versi 21 dengan hasil analisis yaitu persentase nilai rata-rata kelas eksperimen dan kelas kontrol sebesar 7,3\% dan hipotesis Sig. 0,001<0,05. Model inkuiri terbimbing tidak berpengaruh secara signifikan terhadap kreativitas siswa pada materi larutan penyangga.
\end{abstract}

Kata kunci : Inkuiri Terbimbing, Kreativitas, Larutan Penyangga

\section{PENDAHULUAN}

Kreativitas merupakan hakikat sains yaitu sebagai proses dan produk. Kreativitas merupakan hal penting dalam proses pembelajaran karena dapat membuat siswa lebih produktif. Selain itu juga meningkatkan kualitas pengetahuan serta dapat mempermudah mencari jalan keluar dari sebuah permasalahan karena pada dasarnya tujuan akhir pembelajaran adalah menghasilkan siswa yang memiliki pengetahuan dan keterampilan dalam memecahkan masalah yang dihadapi kelak di masyarakat. Sesungguhnya kreativitas dimiliki secara alami pada setiap orang dan merupakan kemampuan dasar bagi setiap individu untuk menjadi seorang ilmuwan besar. Jika kreativitas ini diasah, maka semakin banyak penerus bangsa yang akan menjadi ilmuwan besar. Namun, sangat sedikit guru yang mengembangkan kreativitas karena dianggap menghabiskan waktu yang lebih lama. Pada umumnya kebanyakan guru hanya mengajar bagaimana suatu materi tuntas disampaikan kepada siswa serta bagaimana siswa dapat memperleh ketuntasan belajar sesuai SKM yang ditetapkan sekolah tanpa memikirkan bagaimana siswa belajar dan mengembangkan kemampuan yang dimilikinya, seperti kemampuan berpikir kreatif. Faktanya, siswa hanya dituntut untuk menghafalkan informasi yang disampaikan oleh guru, hal tersebut tentu tidak dapat mengembangkan kemampuan berpikir siswa. Cara belajar demikan, bukanlah cara belajar yang bermakna dan tidak dapat tersimpan dalam memori jangka panjang.

Berdasarkan pengalaman peneliti selama melaksanakan Program Pengalaman Lapangan (PPL) di kelas XI IPA SMA N 2 Kota Bima tahun ajaran 2018/2019 dapat diketahui bahwa pembelajaran kimia kebanyakan masih menggunakan model pembelajaran berupa penugasan langsung dan metode pembelajaran konvensional. Model yang digunakan guru 
kurang mendorong siswa untuk mengembangkan kemampuan berpikir kreatif siswa. Salah satu model pembelajaran yang diasumsikan dapat mendukung terciptanya masyarakat belajar yang dinamis, tidak menjenuhkan dan mampu memacu kreativitas dan interaksi antar siswa serta interaksi antara siswa dengan guru adalah model pembelajaran inkuiri terbimbing. Pemilihan model inkuiri terbimbing sebagai model pembelajaran yang dirasakan sangat sesuai dengan permasalahan yang ada. Pada model inkuiri terbimbing, guru ditempatkan sebagai fasilitator, dalam arti guru memberi bimbingan kepada siswa. Pada model ini, siswa dituntut untuk aktif dalam menemukan ide, konsep atau gagasan pemecahan masalah berdasarkan data dan bahan yang diberikan oleh guru.

Kompetensi dasar yang harus dicapai oleh siswa kelas XI IPA dalam materi larutan penyangga adalah mendeskripsikan sifat larutan penyangga dan peranan larutan penyangga dalam tubuh manusia. Materi pokok larutan penyangga merupakan konsep yang tidak cukup dihafal saja namun terdapat konsep - konsep yang perlu diobservasi melalui kegian ilmiah berupa perhitungan kimia, Pokok bahasan yang demikian menunjukkan adanya keselarasan dengan karakter pembelajaran inkuiri terbimbing.

Beberapa penelitian telah dilakukan untuk mengetahui keefektifan dari pembelajaran inkuiri terbimbing, di antaranya penelitian yang dilakukan oleh Qomaliyah (2016) yang menunjukkan bahwa model Inkuiri terbimbing berbasis literasi sains setelah dikendalikan oleh kovariabel (variabel pretest) berpengaruh positif terhadap hasil belajar materi pokok larutan penyangga. Penelitian yang dilakukan oleh Sulistianingrum, dkk (2017) menunjukan bahwa rata-rata pencapaian keterampilan proses sains peserta didik sebesar $94,70 \%$ dengan kriteria sangat baik. Penelitian Fajariani, dkk (2013) dengan hasil bahwa penerapan model inkuiri mendapatkan respon baik dari siswa dengan persentase rata-rata diatas $69 \%$. Penelitian yang dilakukan oleh Assryanto, dkk (2014) dengan hasil bahwa metode inkuiri terbimbing dapat meningkatkan prestasi belajar siswa pada aspek kognitif dan afektif siswa pada materi larutan penyangga. Berdasarkan permasalahan yang telah dipaparkan sebelumnya, maka penulis bermaksud untuk melakukan penerapan terhadap Pengaruh Model Pembelajaran Inkuiri Terbimbing terhadap kreativitas siswa di kelas XI SMAN 2 Kota Bima

\section{METODELOGI PENELITIAN}

Rancangan penelitian yang digunakan pada penelitian ini adalah rancangan eksperimen semu (Quasy Experimental) dengan posttest-only control design, seperti yang tertera pada Tabel 1.

Tabel 1. Desain Eksperimen Posttest - Only Control Design

\begin{tabular}{|c|c|c|}
\hline Subjek & Perlakuan & Post-Test \\
\hline $\mathrm{E}$ & $\mathrm{X}_{1}$ & $\mathrm{O}_{1}$ \\
$\mathrm{~K}$ & $\mathrm{X}_{2}$ & $\mathrm{O}_{2}$ \\
\hline
\end{tabular}

Sugiyono (2013) modifikasi dalam jurnal FMIPA (2017)

Keterangan;

E : Kelas Eksperimen

$\mathrm{K}$ : Kelas Kontrol

$X$ : Perlakuan dengan menggunakan pembelajaran inkuiri terbimbing

$\mathrm{Y}$ : Perlakuan dengan menggunakan pembelajaran penugasan langsung 
01: Nilai post-test peserta didik yang dibelajarkan dengan pembelajaran inkuiri terbimbing

O2: Nilai post-test peserta didik yang dibelajarkan dengan pembelajaran penugasan langsung.

Subjek penelitian yang digunakan adalah siswa kelas XI MIA 5 dan XI MIA 6 SMAN 2 Kota Bima. Kelas XI MIA 5 digunakan sebagai kelas eksperimen yang dibelajarkan dengan pembelajaran inkuiri terbimbing dan XI MIA 6 SMA digunakan sebagai kelas kontrol yang dibelajarkan dengan pembelajaran penugasan langsung. Waktu penelitian dilaksanakan pada tanggal 15 sampai dengan 24 Mei pada semester genap tahun ajaran 2018/2019.

Variabel bebas pada penelitian ini adalah model yang diterapkan dan variabel terikatnya adalah kreativitas dan materi yang diajarkan adalah larutan penyangga. Instrumen tes yang digunakan berupa soal essay sebanyak 6 butir yang mengukur empat indikator kreativitas yaitu fluency, flexibility, elabotion, dan originality. Instrumen divalidasi oleh dosen STKIP Bima dengan guru matapelajaran SMAN 2 Kota Bima. Teknik analisis data menggunakan aplikasi SPSS versi 21.

\section{HASIL DAN PEMBAHASAN}

\section{Hasil Post-Test Kreativitas Siswa}

Data posstest hasil tes kreativitas siswa pada kelas eksperimen dan kelas kontrol diperoleh setelah semua proses pembelajaran dilaksanakan. Ringkasan data tertera pada Tabel berikut;

Tabel 2. Ringkasan Data Hasil posttest kelas eksperimen dan kelas kontrol

\begin{tabular}{|c|c|c|c|}
\hline & & $\bar{x}$ & $\bar{Y}$ \\
\hline \multirow{2}{*}{$\mathrm{N}$} & Valid & 23 & 23 \\
\hline & Missing & 0 & 0 \\
\hline Mean & & 66.26 & 58.96 \\
\hline Median & & 67.00 & 58.00 \\
\hline Mode & & 67 & $53^{a}$ \\
\hline Std. Deviation & & 6.923 & 6.772 \\
\hline Variance & & 47.929 & 45.862 \\
\hline Range & & 24 & 24 \\
\hline Minimum & & 55 & 48 \\
\hline Maximum & & 79 & 72 \\
\hline
\end{tabular}

Selanjutnya data posttest dari kedua kelas tersebut dihitung berdasarkan indikator masing-masing soal tes kreativitas yang diberikan. Penyajian data berdasarkan indikator kreativitas dapat dilihat pada tabel berikut;

Tabel 3. Nilai Rata-rata Posttest Indikator Kreativitas

\begin{tabular}{|l|l|c|l|c|l|}
\hline \multirow{2}{*}{ No } & \multirow{2}{*}{ indikator } & \multicolumn{4}{|c|}{ Nilai Rata-Rata (\%) } \\
\cline { 3 - 6 } & $\begin{array}{c}\text { Kelas } \\
\text { Eksperimen }\end{array}$ & Kriteria & $\begin{array}{c}\text { Kelas } \\
\text { Kontrol }\end{array}$ & \multicolumn{1}{|c|}{ Kriteria } \\
\hline 1 & Fluency & 92,39 & $\begin{array}{l}\text { Sangat } \\
\text { Kreatif }\end{array}$ & 88 & Kreatif \\
\hline
\end{tabular}




\begin{tabular}{|l|l|l|l|l|l|}
2 & Flexibility & 64,19 & $\begin{array}{l}\text { Cukup } \\
\text { Kreatif }\end{array}$ & 57,35 & Cukup Kreatif \\
\hline 3 & Elaboration & 73,91 & Kreatif & 63,26 & Cukup Kreatif \\
\hline 4 & Originality & 59,11 & $\begin{array}{l}\text { Cukup } \\
\text { Kreatif }\end{array}$ & 54,73 & Cukup Kreatif \\
\hline
\end{tabular}

\section{Hasil Pengujian Prasyarat Analisis Data Post-Test}

\section{Uji Normalitas}

Hasil uji normalitas post-test kelas eksperimen dan kelas kontrol dapat dilihat seperti pada tabel dibawah ini

Tabel 4. Hasil Uji Normalitas Post-Test

\begin{tabular}{|c|c|c|c|}
\hline \multirow{2}{*}{ kelas } & \multicolumn{3}{|c|}{ Kolmogorov-Smirnov } \\
\cline { 2 - 4 } Nilai & Statistic & $\mathrm{df}$ & Sig. \\
\hline \hline $\begin{array}{l}\text { kelas eksperimen } \\
\text { (inkuiri terbimbing) } \\
\text { kelas kontrol } \\
\text { (penugasan langsung) }\end{array}$ & .114 & 23 & $.200^{*}$ \\
\hline
\end{tabular}

\section{Uji Homogenitas}

Ringkasan data hasil uji homogenitas post-test kelas eksperimen dan kelas kontrol dapat dilihat pada tabel berikut;

Tabel 5. Hasil Uji Homogenitas Post-Test



\section{Uji Hipotesis}

Hasil perhitungan uji hipotesis hasil Post-test disajikan dalam tabel dibawah ini;

Tabel 6. Data Hasil Uji Hipotesis

\begin{tabular}{|c|c|c|c|c|c|}
\hline & \multicolumn{2}{|c|}{$\begin{array}{c}\text { Levene's Test for } \\
\text { Equality of Variances }\end{array}$} & \multicolumn{3}{|c|}{ t-test for Equality of Means } \\
\cline { 2 - 6 } & F & Sig. & t & df & Sig. (2-tailed) \\
\hline
\end{tabular}




\begin{tabular}{|l|r|r|r|r|r|}
\hline Nilai $\begin{array}{l}\text { Equal variances } \\
\text { assumed } \\
\begin{array}{l}\text { Equal variances not } \\
\text { assumed }\end{array}\end{array}$ & .029 & .865 & 3.617 & 44 & .001 \\
\hline
\end{tabular}

\section{PEMBAHASAN}

berdasarkan hasil analisis pada tabel 4 dapat diketahui bahwa kedua sampel berdistribusi normal. Hal ini dikarenakan nilai signifikan yang diperoleh dari kedua kelas lebih besar dari nilai signifikan 5\%. Sehingga dapat disimpulkan bahwa kedua sampel berdistribusi normal. Sedangkan pada pengujian homogenitas kedua sampel memperoleh nilai signifikan yang sama dalam artian bahwa kedua sampel homogen karena memenuhi kriteria yaitu nilai sig. $>0,05$ yang artinya sampel homogen seperti yang tertera pada tabel 5.

Setelah diterapkan model pembelajaran inkuiri terbimbing pada kelas eksperimen dan model pembelajaran penugasan langsung pada kelas kontrol diperoleh skor rata-rata kelas eksperimen lebih tinggi dibandingkan kelas kontrol. Dari data hasil analisis frekuensi pada tabel 4 dapat dibuat grafik perbandingan rata-rata hasil posttest antara kelas eksperimen dan kelas kontrol, perhatikan gambar dibawah ini:

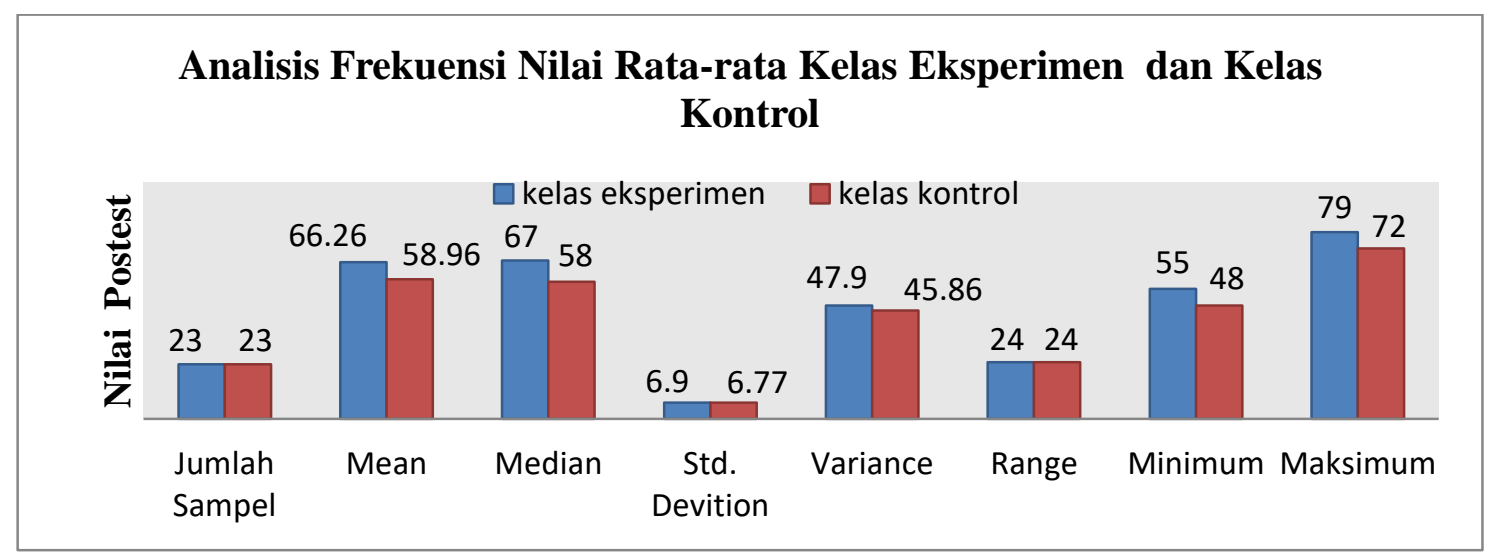

Gambar 1. Perbandingan rata-rata hasil posttest kelas eksperimen dan kelas kontrol

Gambar 1 memperlihatkan bahwa dengan jumlah sampel yang sama antara kelas eksperimen dan kelas kontrol yaitu 23 menghasilkan nilai rata-rata variabel kreativitas kelas eksperimen lebih tinggi dari kelas kontrol. Hal ini dapat diamati dari nilai rata-rata kelas eksperimen sebesar $(66,26)$ dengan vasrians $(47,93)$ lebih tinggi dari pada nilai rata-rata kelas kontrol sebesar $(58,96)$ dengan varians $(45,86)$. Berdasarkan nilai ratarata yang diperoleh maka selisih atau perbandingan persentase antara kelas eksperimen dengan kelas kontrol yaitu sebesar 7,3\%, artinya terdapat pengaruh model inkuiri terbimbing terhadap kreativitas tetapi tidak berpengaruh secara signifikan. Penerapan model guided inquiry dalam proses pembelajaran menghasilkan pengaruh yang positif terhadap perkembangan kreativitas siswa. 




Gambar 2. Persentase indikator kreativitas kelas eksperimen dan kelas kontrol

Perhitungan tiap indikator kreativitas kedua sampel kelas penelitiaan menunjukan hasil yang cukup berbeda. Indikator berpikir lancar (fluency) kelas eksperimen berada pada kriteria sangat kreatif dengan nilai rata-rata 92,39\% sedangkan kelas kontrol berada pada kriteria kreatif dengan nilai rata-rata $88 \%$. Hal ini berarti bahwa pada kelas eksperimen siswa lebih mampu mencetuskan banyak gagasan yang relevan. Indikator berpikir luwes (flexibility) kelas eksperimen mendapatkan nilai rata-rata sebesar $64,19 \%$ dengan kriteria cukup kreatif sedangkan kelas kontrol mendapatkan nilai sebesar 57,35\% dengan kriteria cukup kreatif. Pada Indikator flexibility kelas eksperimen dan kelas kontrol memiliki nilai rata-rata yang berbeda namun berada pada kriteria yang sama yang artinya kedua kelas sampel memiliki kemampuan yang sama dalam menghasilkan gagasan, jawaban, atau pertanyaan yang bervariasi sehingga siswa mampu melihat dari sudut pandang yang berbeda. Pada indikator merinci (elaboration) kelas eksperimen berada pada kriteria kreatif dengan nilai rata-rata $73,91 \%$ sedangkan kelas kontrol mendapatkan nilai rata-rata $63,26 \%$ dengan kriteria cukup kreatif. Pada indikator elaboration nilai rata-rata kelas eksperimen lebih tinggi dari pada kelas kontrol. Hal ini berarti bahwa kelas eksperimen mampu memperkaya gagasan dan mencari arti yang lebih mendalam terhadap jawaban atau permasalahan. Pada indikator originality nilai rata-rata kelas eksperimen 59,11\% dengan kriteria cukup kreatif dan kelas kontrol 54,73\% dengan kriteria cukup kreatif pula. Artinya walaupun kedua kelas memiliki nilai rata-rata yang berbeda namun bearada pada kriteria yang sama maka kedua kelas memiliki kemampuan yang sama untuk mengahsilkan beberapa reaksi yang orisinil.

Hal tersebut semakin jelas adanya setelah dilakukan pengujian hipotesis dengan uji Independent Sample T Test data posttest seperti yang tertera pada tabel 6. Pada tabel tersebut diperoleh nilai $F$ yang mengansumsikan bahwa kedua varian sama adalah 0,029 dengan nilai $t=3,617$, derajat kebebasan $d f=44$, dan diperoleh Sig. (2-tailed) 0,001. Karena Sig. 0,001 < 0,05 sehingga memenuhi kriteria dimana Ho ditolak dan hipotesis alternatif $\mathrm{(Ha}$ ) diterima, artinya terdapat perbedaan yang signifikan antara rata-rata skor posttest kelas eksperimen dengan rata-rata skor posttest kelas kontrol dimana model inkuiri terbimbing yang diterapkan menunjukan peningkatan yang signifikan terhadap kreativitas siswa pada kelas eksperimen. Dengan kata lain, terdapat pengaruh model inkuiri terbimbing terhadap kreativitas siswa pada materi larutan penyangga. Hal ini membuktikan pendapat Assryanto,. dkk (2014) yang menyatakan bahwa keberhasilan belajar siswa tergantung pada 
penggunaan model pembelajaran sebagai sarana dalam kegiatan belajar mengajar untuk menyampaikan ilmu pengetahuan kepada siswa secara efektif dan meningkatkan. Sedangkan penggunaan model pembelajaran penugasan langsung dapat dijadikan salah satu penyebab rendahnya kemampuan kreatif siswa. Karena proses pembelajaran hanya berorientasi pada penguasan sejumlah informasi atau konsep belaka, penekanannya lebih kepada hapalan tanpa dikembangkan dan ditelaah secara terperinci oleh siswa tersebut sehingga kemampuan kreatif siswa tak dapat dikembangkan. Hal ini senada dengan yang dikemukan oleh Parnes dalam Utami munandar melalui bahwa siswa menerima begitu banyak instruksi bagaimana melakukan sesuatu disekolah, di rumah dan di dalam pekerjaan sehingga kebanyakan dari siswa kehilangan hampir setiap kesempatan untuk kreatif.

\section{KESIMPULAN}

Berdasarkan rumusan masalah dan hasil penelitian yang telah dilakukan, dapat disimpulkan bahwa pembelajaran dengan model inkuiri terbimbing berpengaruh terhadap kreativitas siswa pada materi larutan penyangga. Perbandingan persentase kelas eksperimen dan kelas kontrol sebesar 7,3\% dan hipotesis sig.2.tailed $<5 \%$, artinya terdapat pengaruh model inkuiri terbimbing terhadap variabel kreativitas tetapi tidak secara signifikan.

\section{DAFTAR PUSTAKA}

Assriyanto, K, E. "Pengaruh Model Pembelajaran Berbasis Masalah Melalui Metode Eksperimen Dan Inkuiri Terbimbing Ditinjau Dari Kreativitas Siswa Pada Materi Larutan Penyangga Di Sma N 2 Sukoharjo Tahun Ajaran 2013/2014". Jurnal Pendidikan Kimia (JPK), 3 (3).

Fajariani, Tria Endah., Ismono. "Penerapan Model Pembelajaran Inkuiri Pada Materi Pokok Larutan Penyangga Untuk Melatih Keterampilan Berpikir Tingkat Tinggi Siswa Kelas Xi di SMA Negeri 1 Plemahan Kediri". Journal Of Chemistry Education. II (2).

Munandar, Utami. 1999. Mengembangkan Bakat dan Kreativitas Anak Berbakat. Jakarta: Rineka Cipta.

Mutmainnah, P. A. 2019. EFEKTIVITAS ALAT PERAGA "KARPET KIMIA" DALAM PEMBELAJARAN STRUKTUR ATOM DAN SISTEM PERIODIK UNSUR. JURNAL REDOKS: JURNAL PENDIDIKAN KIMIA DAN ILMU KIMIA, 2(01), 11-17.

Qomaliyah, Eka Nurul., dkk. 2016. Pengaruh Model Pembelajaran Inkuiri Terbimbing Berbasis Literasi SainsTerhadap Hasil Belajar Materi Pokok Larutan Penyangga. Jurnal Pijar MIPA, XI (2), 105-109. 